THE CULTURE OF JAPANESE FASCISM 
ASIA-PACIFIC: CULTURE, POLITICS, AND SOCIETY

Editors: Rey Chow, H. D. Harootunian, and Masao Miyoshi 


\title{
THE CULTURE OF JAPANESE FASCISM
}

\author{
Edited by Alan Tansman
}

DUKE UNIVERSITY PRESS

DURHAM AND LONDON

2009 
() 2009 Duke University Press

All rights reserved

Printed in the United States of

America on acid-free paper $\otimes$

Designed by Amy Ruth Buchanan

Typeset in Quadraat by Tseng

Information Systems, Inc.

Library of Congress Cataloging-

in-Publication Data appear on the

last printed page of this book.

Duke University Press gratefully acknowledges the support of

Columbia University, which provided funds toward the production of this book. 